Grégor Puppinck

Europejskie Centrum Prawa i Sprawiedliwości w Strasburgu ${ }^{1}$

ORCID: 0000-0001-8211-8333

\title{
Cenzura wypowiedzi dotyczacych islamu w Europejskim Trybunale Praw Człowieka: uderzający przypadek sprawy E.S. przeciwko Austrii
}

The censorship of speech about Islam before the European Court of Human Rights: the appalling case of E. S. v. Austria

\begin{abstract}
Abstrakt: Europejski Trybunał Praw Człowieka nierzadko wydawał wyroki chroniące osoby, którym zarzucano bluźnierstwo zwłaszcza przeciwko religii chrześcijańskiej. Tymczasem podtrzymał wyrok skazujący za bluźnierstwo Elisabeth Sabaditsch-Wolff wydany przez austriackie sądy, która publicznie określiła znany ożenek Mahometa z małoletnią dziewczynką jako pedofilię. Sąd austriacki oficjalnie przyznał, że musiał te słowa potępić w imię pokoju religijnego. ETPC podtrzymał ten wyrok w imię tolerancji religijnej, niejako zawieszając wcześniejsze orzecznictwo i cenzurując wszelkie wypowiedzi krytykujące islam, choćby były one zgodne z prawdą. To naruszenie wolności wypowiedzi jest usprawiedliwiane nowym pozytywnym obowiązkiem nałożonym na Państwa przez Trybunał, składającym się na „zapewnieniu pokojowej koegzystencji wszystkich religii i tych, którzy nie przynależą do żadnej grupy religijnej, poprzez zapewnienie wzajemnej tolerancji”. W ten sposób każda wypowiedź, nawet prawdziwa, może zostać uznana za naganną jako wyraz nietolerancji religijnej, jeżeli mogłaby prowadzić do napięć społecznych.
\end{abstract}

Słowa kluczowe: Austria, Europejski Trybunał Praw Człowieka, islam, Mahomet, wolność słowa

Abstract: The European Court of Human Rights has often issued judgments protecting individuals who have been accused of blasphemy, especially against the Christian religion. Meanwhile, he upheld the condemnation of the conviction

${ }^{1}$ ECLJ był jedyną organizacją upoważnioną do interwencji w sprawie E.S. p. Austrii poprzez złożenie pisemnych uwag do Europejskiego Trybunału Praw Człowieka. 
decision of the blasphemy Elisabeth Sabaditsch-Wolff by Austrian courts, who publicly described Mohammed's known marriage to a minor girl as pedophilia. The Austrian court officially confessed that it had to condemn these words in the name of religious peace. The ECtHR upheld this judgment in the name of religious tolerance, somewhat suspending previous case law and not censoring any statements criticizing Islam, even if they were true. This violation of freedom of expression is justified by a new positive obligation imposed on you by the Tribunal, consisting in „ensuring peaceful coexistence of all religions and those who do not belong to any religious group, by ensuring mutual tolerance." In this way, any statement, even a true one, can be considered reprehensible as an expression of religious intolerance, if it could lead to social tensions.

Keywords: Austria, European Court of Human Rights, freedom of speech, Islam, Muhammad

W 2013 r. austriacki Sąd Najwyższy skazał Elisabeth Sabaditsch-Wolff za publiczne zadanie pytania: „Pięćdziesięciosześcioletni mężczyzna z sześcioletnia dziewczynka (...) Co to jest, jeśli nie pedofilia?” [ECHR 2018: no. 38450/12, 13]. Prelegentka odwołując się do udowodnionych faktów historycznych z życia Mahometa, adresowała swoją wypowiedź do trzydziestu osób obecnych na seminarium zatytułowanym „Podstawowa wiedza na temat Islamu”. Miała ona stanowić ostrzeżenie przed obecną w kulturze muzułmańskiej praktyką zawierania małżeństw z dziewczynkami przed osiągnięciem przez nie dojrzałości płciowej, idąc za przykładem Mahometa, który ożenił się z sześcioletnią Aiszą i skonsumował małżeństwo, gdy osiągnęła ona dziewięć lat. W następstwie skargi wniesionej przez obecnego na sali dziennikarza, pani Sabaditsch-Wolff została skazana na podstawie przepisu karnego, którego treść zakazuje bluźnierstwa².

Następnie zwróciła się ona do Europejskiego Trybunału Praw Człowieka (ETPC), który ku powszechnemu zdumieniu przyjął argumentację sądów austriackich i zatwierdził wyrok skazujący jednogłośnym wyrokiem z dnia 25 października 2018 r. Siedmiu sędziów Trybunału uznało, że ta kobieta miała na celu nie tyle publiczne przekazanie obiektywnych informacji co „pokazanie, że Prorok Mahomet

\footnotetext{
2 „Dyskredytowanie doktryn religijnych”, „Kto w okolicznościach, w których jego zachowanie może wzbudzić uzasadnione oburzenie, publicznie dyskredytuje lub obraża osobę lub rzecz będąca przedmiotem czci w kościele lub wspólnocie religijnej istniejącej na terenie kraju, bądź też dogmat, zgodny z prawem zwyczaj, lub legalna instytucję tego kościoła lub wspólnoty religijnej, podlega karze do sześciu miesięcy więzienia lub grzywnie dziennej przez okres do 360 dni" [Austriacki kodeks karny, rozdz. 8, art. 188].
} 
nie jest godny czci" [tamże: 52]. W uzasadnieniu wyroku Sąd stwierdził, że insynuowanie, iż Mahomet był „pedofilem” byłoby „uogólnieniem nie znajdującym oparcia w faktach" [tamże: 57] z uwagi na to, że kontynuował on związek z Aiszą przez lata, oraz że zawierał także małżeństwa ze starszymi kobietami. Zdaniem Sądu uwagi te „byly w stanie wzbudzić uzasadnione oburzenie” muzułmanów i stanowily „szkodliwe naruszenie ducha tolerancji, który stanowi jedna z podstaw społeczeństwa demokratycznego" [tamże]. Uwagi te mogą zatem być potępione za podżeganie do nietolerancji religijnej.

Dnia 19 marca 2019 r. [ECHR 2019] Trybunał odrzucił wniosek powódki o przekazanie sprawy do Wielkiej Izby. Wyrok skazujący Elisabeth Sabaditsch-Wolff stał się prawomocny.

Rzadko zdarza się, by wyrok Trybunału spotykał się z tak jednomyślną krytyką. Większość zachodnich komentatorów - tak konserwatywnych, jak i wolnomyślicieli - była zszokowana decyzją Piątej Sekcji Trybunału. Przedstawioną przez nią argumentację uznano za wyjątkowo nieprzekonywującą (I). Wyrok spotkał się jednak z uznaniem władz sunnickich, które popierają anty-bluźniercze przepisy (II). Sprawa nie została przekazana do Wielkiej Izby pomimo publicznych nacisków (III). Ostatecznie ETPC postanowił w tej sprawie opowiedzieć się za „pokojem religijnym” za cenę prawdy i sprawiedliwości (IV).

\section{Niedociągnięcia $w$ argumentacji Izby}

Zdaniem Trybunału „wypowiedzi skarżacej były w stanie wzbudzić uzasadnione oburzenie, zważywszy że nie zostaly one dokonane w sposób obiektywny, mający na celu przyczynienie się do debaty w interesie publicznym" [ECHR 2018: no. 38450/12, 52]. Jednakże „podstawowa wiedza na temat islamu”, do której te twierdzenia miały się odnosić, bez wątpienia leży w interesie publicznym. Islam nie może zostać wyłączony z ram debaty dotyczącej idei na tej podstawie, że jako całościowy zestaw doktryn ma on istotny wymiar religijny. Islam ma także wymiar społeczny, polityczny i historyczny, który musi podlegać otwartej dyskusji [Ahmari S. 2018]. Z uwagi na skalę zjawiska, opinia publiczna musi być informowana, a informacje te, o ile nie wprowadzają w błąd, mogą zasadnie mieć charakter krytyczny. Mahomet jest także postacią polityczną, która nadal wywiera znaczny wpływ, zatem powinno być możliwe szerokie krytykowanie go w kontekście debaty politycznej.

Co więcej, należy zwrócić uwagę, że zastrzeżenia podniesione przez powódkę są bezpośrednio związane $\mathrm{z}$ trwającą nadal praktyką zawierania małżeństw 
z dziewczynkami, które nie osiągnęły jeszcze dojrzałości płciowej, w krajach znajdujących się pod wpływem kultury muzułmańskiej. Skarżąca powiązała tę praktykę z faktem, iż „Mahomet postrzegany jest jako doskonaty mężczyzna, doskonały człowiek, doskonały muzułmanin. Oznacza to, że najwyższym przykazaniem dla muzutmanina jest naśladowanie Mahometa, życie jego życiem" [ECHR 2018: no. 38450/12, 13]. Według Funduszu Ludnościowego Narodów Zjednoczonych (UNFPA) w latach 2011-2020, 50 milionów dziewcząt poniżej 15 roku życia zostanie wydanych za mąż. Zjawisko to jest także marginalnie obecne w Europie, zatem poszukiwanie jego przyczyn leży $\mathrm{w}$ interesie publicznym. W interesie publicznym leży otwarta debata na temat pedofilii w kontekście religijnym, nie tylko w Kościele, ale także w innych religiach. Pedofilia w świecie muzułmańskim nie powinna być traktowana inaczej, niż w innych religiach.

Trybunał uznał też, że insynuowanie, iż Mahomet był „pedofilem”, byłoby „osądem wartościującym, pozbawionym wystarczającego oparcia w faktach" [tamże: 54]. Tym samym zgodził się z austriacką jurysdykcją, według której Elisabeth SabaditschWolff „w sposób subiektywny przypisała Mahometowi pedofilię jako ogólną preferencje seksualną, nie informując jednocześnie publiczności w sposób neutralny o tle historycznym". Krytycy słusznie twierdzą, że tym wyrokiem sędziowie ze Strasburga zrelatywizowali przemoc dokonaną wobec 9-letniej dziewczynki.

Niektórzy krytycy zwracają uwagę, że choć skonsumowanie małżeństwa pomiędzy Mahometem a Aiszą jest przedmiotem sporów historycznych [zob. np.: FrancoisCerrah 2012], austriackie sądy oraz ETPC nie zaprzeczyły, że była to oparta na faktach prawda [Bougiakiotis 2018]. Skupiły się natomiast na kwestii właściwego określenia, jakim należałoby tę rzeczywistość opisać, a zatem na debacie odnośnie zastosowania współczesnego określenia („pedofilia”) do opisu faktu historycznego (skonsumowania małżeństwa z dzieckiem w VII wieku). Profesor Stijn Smet z żalem przyjął "nadzwyczaj wąskie spojrzenie [Trybunału] na sprawę", sprowadzające się do pytania o to, czy „odbycie stosunku seksualnego zjednym dzieckiem 1400 lat temu wystarcza, by zostać dziś nazwanym pedofilem" [Smet 2018]. Inny komentator napisał: nie jest to "nic innego, jak kwestia drobiazgowego sporu semantycznego na temat terminu pedofil" [Armstrong 2018]. Rzeczywiście, nie powinno być rolą ETPC decydowanie o zasadności użycia językowego anachronizmu.

Co więcej, można zastanawiać się, jaki „stopień dowodu faktycznego powinien być przyjęty” [ECHR 2018: no. 38450/12, 48] aby osiągnąć „,wystarczające oparcie w faktach" przy wyrażaniu sądu ocennego [tamże: 54]. Zgodnie z orzecznictwem 
Trybunału, „o ile istnienie faktów można wykazać, o tyle prawdziwość sadów ocennych nie podlega dowodzeniu”, ponieważ ,wymóg udowodnienia prawdziwości sq̨du ocennego jest niemożliwy do spelnienia" [zob. np.: ETPC 2018: nr 18597/13, \$ 68]. Jednakże nawet sąd ocenny nie może być pozbawiony jakiejkolwiek podstawy faktycznej. W tej sytuacji powódka odwołała się w swojej wypowiedzi do źródła uznawanego przez islam sunnicki, tj. hadisu według Sahiha al-Bukhariego [Bukhari: book 58, number 234]. Za fakt należy uznać co najmniej to, że muzułmanie sunniccy uznają to za źródło oparte na faktach. Domagając się wyższego „stopnia dowodu faktycznego" Trybunał zażądał niemożliwego, odchodząc przy tym od własnego orzecznictwa.

\section{Opowiedzenie się za przepisami dotyczącymi bluźnierstwa ku aprobacie władz sunnickich}

W połowie pierwszej dekady XXI wieku pojawił się silny trend za zniesieniem kryminalizacji bluźnierstwa. Wyłania się on w szczególności z szeregu wypowiedzi organów politycznych. Zgromadzenie Parlamentarne Rady Europy (PACE) wydało w 2007 r. rekomendację, zgodnie z którą „,bluźnierstwo jako obraza wobec religii nie powinno stanowić przestępstwa karnego" zaś "prawo krajowe powinno jedynie penalizować te wypowiedzi w kwestiach religijnych, które celowo i w znacznym stopniu zakłócaja porządek publiczny i stanowia podżeganie do publicznej przemocy" [PACE 2007: 4, 15]. W 2016 r. specjalny sprawozdawca ONZ ds. wolności religii i przekonań, prof. Heiner Bielefeldt, przedłożył Radzie Praw Człowieka raport tematyczny, w którym zawarł rekomendację zniesienia przepisów dotyczących bluźnierstwa, będących zaprzeczeniem tak wolności wypowiedzi, jak i religii [Council for Human Rights 2015: 84].

Poprzez opowiedzenie się za przepisami dotyczącymi bluźnierstwa ETPC wyraźnie przeciwstawia się temu trendowi. Niektórzy komentatorzy zwrócili uwagę na zbieg okoliczności, który sprawił, że zaledwie dwa dni po ogłoszeniu wyroku w sprawie E.S. przeciwko Austrii Irlandia przegłosowała w referendum usunięcie istniejących od lat przepisów dotyczących bluźnierstwa ze swojej konstytucji, idąc tym samym za tendencją obecną w większości krajów Europy [Wood 2018]. Londyński adwokat Matthew Scott stwierdził, że „popierając austriackie przepisy dotyczace bluźnierstwa [ETPC] opowiedział siępo stronie prześladowców na catym świecie, nie robiąc nic dla prześladowanych" [Scott 2018]. Rzeczywiście, podjęta przez ETPC decyzja uzasadniałaby tak wysoki wyrok skazujący za karykatury zamieszczone w Charlie Hebdo, jak i książkę o Mahomecie autorstwa Woltera [Puppinck 2018]. Inny europejski profesor określił ten wyrok mianem „historycznego posunięcia”, 
biorąc pod uwagę ,aktualny klimat polityczny w Europie, w którym tylko najodważniejsi karykaturzyści mieliby śmiałość żartować z Proroka Mahometa" [Cotte 2018].

Uniwersytet Al-Azhar, Pakistan i prasa arabska z zadowoleniem przyjęły wyrok Trybunału, który pozwala im uzasadnić stosowane przez siebie represje w obszarze wolności wypowiedzi w kwestiach religijnych [Puppinck 2019]. Ich wypowiedzi nie są zaskakujące - wiadomo przecież, że gromadząca 57 krajów muzułmańskich Organizacja Współpracy Islamskiej (OWI) od 1999 roku walczy o wprowadzenie międzynarodowego zakazu „zniesławiania religii”, czyli bluźnierstwa [ECL] 2008-2010] $]^{3}$.

Obserwatorium Islamofobii prestiżowego Uniwersytetu Al-Azhar, będącego najwyższym autorytetem islamu sunnickiego, wyraziło swoje poparcie dla decyzji Trybunału, określając ją jako „odważną” [2018]. Dostrzegło w niej ogólne potępienie "bluźnierstw przeciwko Prorokowi”, przyczyniające się do „zmniejszenia problemu islamofobii” w sytuacji, gdy „w 2050 roku liczba muzulmanów w Europie może sięgnać 14\%” [tamże]. W związku z tą decyzją wezwało „rządy na całym świecie oraz międzynarodowe instytucje praw człowieka do podjęcia kroków na rzecz przeciwdziałania próbom zniesławiania innych na mocy wolności

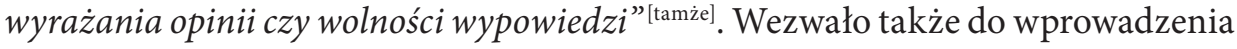
„odstraszających przepisów prawnych i sankcji wobec wszystkich, którzy próbuja atakować sity religijne" [tamze]. W podobnym duchu Qari Hanif Jalandhari, Sekretarz Generalny największej światowej federacji szkół koranicznych (10.000 madrasów), uznał tę decyzję za „bardzo ważny krok” i zwrócił się do Organizacji Narodów Zjednoczonych z apelem o wypracowanie globalnych przepisów „potępiających każdego, kto dopuszcza się bluźnierstwa przeciw świętym księgom lub postaciom wszystkich religii"'. Z kolei Rektor Uniwersytetu Bahauddin Zakariya, dr Tahir Amin, stwierdził, że wyrok Trybunału jest „niewątpliwie znacząca i historyczna decyzja".

Premier Pakistanu Imran Khan „z zadowoleniem przyjąt ostatnia decyzje Europejskiego Trybunału Praw Człowieka, która nie dopuszcza do aktów profanacji pod pozorem wolności wypowiedzi” [Government of Pakistan i in. 2018]. Zwracając

\footnotetext{
3 „Lutter contre la diffamation des religions”, Rapport en réponse à la consultation du Bureau du Haut-commissaire aux droits de l'homme des Nations Unies sur le suivi par la France de la Résolution 7/19 du Conseil des droits de l'homme du 27 mars 2008 sur „la lutte contre la diffamation des religions".

4 „EU court lauded for upholding verdict against blasphemy” [The Nation 2018].
} 
się do Prezydenta Parlamentu Europejskiego wyraził „nadzieję, że kraje Europy zastosuja się do decyzji Trybunału i podejma środki dla zapewnienia większego poszanowania religii i międzyreligijnej harmonii” [tamże]. Wyraził także „poważna obawę rządu i narodu pakistańskiego odnośnie bluźnierczych karykatur Świętego Proroka, podkreślając konieczność podwojenia wysiłków w krajach Europy dla unikania takich prowokacyjnych incydentów, podnoszenia świadomości religijnej oraz wrażliwości wobec muzułmanów, w szczególności czci, jakq otaczany jest Prorok Mahomet” [tamże]. Minister ds. praw człowieka w jego rządzie wtórowała $\mathrm{mu}$, „wzywajac świat zachodni do poszanowania religii” [Government of Pakistan i in. 2019]. Dodała także, że „wolność wypowiedzi nie chroni bluźnierstwa”[tamże]. Rzeczywiście, oprócz symbolicznego przypadku Asii Bibi, według danych Centrum Sprawiedliwości Społecznej w latach 1987-2016 w Pakistanie około 1500 osób zostało oskarżonych o bluźnierstwo, a ponad 70 zostało zamordowanych od 1990 r. na podstawie takich zarzutów. W 2017 r. trzydziestoletni mężczyzna został skazany na śmierć za rzekome „obrażenie Proroka Mahometa” na Facebooku [Rasmussen 2017]. Premier Imran Khan ponownie oświadczył w czerwcu 2018 r. wobec grona imamów, że zamierza „popierać i bronić artkułu 295c" kodeksu karnego, który karze śmiercią lub dożywociem każdego, kto „profanuje imię Świętego Proroka Mahometa" [Barker 2018].

Decyzja Trybunału oraz opisane powyżej reakcje skłoniły wiele podmiotów europejskich do walki o przekazanie sprawy do Wysokiej Izby.

\section{Trybunał zignorował publiczny sprzeciw wobec preferencyjnego trakto- wania islamu}

Prawnicy Elisabeth Sabaditsch-Wolff złożyli wniosek o przekazanie sprawy do Wielkiej Izby. Wnioski takie są uwzględniane w drodze wyjątku (w 5\% przypadków), gdy Trybunał uznaje, że chodzi o ,istotne pytania mające znaczenie dla interpretacji lub stosowania Konwencji lub jej Protokołów, lub też istotna kwestie mająca znaczenie ogólne”.

Trybunał mógł zgodzić się na ponowne rozpatrzenie sprawy E.S. przeciwko Austrii w Wielkiej Izbie. Istotnie, wyrok wyraźnie odbiegał przecież od orzecznictwa Trybunału. Wcześniej, w słynnej sprawie Handyside przeciwko Wielkiej Brytanii [1976: nr 5493/72, 49] Trybunał wprowadził zasadę, zgodnie z którą wolność wypowiedzi „odnosi się nie tylko do 'informacji' czy 'idei' odbieranych przychylnie bądź uznawanych za nieszkodliwe lub neutralne, ale także takich, które obrażaja, szokuja lub są niewygodne dla Państwa czy też określonej części populacji”. Ponadto 
zwrócił uwagę osób wierzących na obowiązek „tolerowania i akceptacji odrzucenia ich przekonań religijnych przez inne osoby, a nawet rozpowszechniania przez nie doktryn wrogich wobec ich własnej wiary" [ECHR 1994: no. 13470/87, 47]. $\mathrm{Na}$ tej podstawie sędziowie ze Strasburga wielokrotnie gwarantowali wolność wypowiedzi w przypadku anty-religijnych zachowań skierowanych przeciwko chrześcijaństwu. W lipcu 2018 r. zapewnili ochronę słynnej grupie punkowej Pussy Riot potępionej w Rosji za zorganizowanie w chórze Katedry Moskiewskiej „performansu”, w trakcie którego jego członkinie wykrzykiwały między innymi "gówno, gówno, gówno $P^{* * * ” ~[E C H R ~ 2018: ~ 38004 / 12] . ~ S t w i e r d z i l i ~ t a k z ̇ e, ~ z ̇ e ~ L i t w a ~}$ nie może nakładać sankcji za rozpowszechnianie bluźnierczych reklam przedstawiających Chrystusa i Maryję Dziewicę jako pokrytych tatuażami, lubieżnych ćpunów [ECHR 2018: 69317/14, 31].

W 2018 roku w sprawie E.S. przeciwko Austrii [no. 38450/12, 57-58] Trybunał postąpił natomiast dokładnie odwrotnie: potępił panią Sabaditsch-Wolff uznając, że jej celem było nie tyle poinformowanie opinii publicznej, co "poniżenie”. Mahometa i wykazanie, że „nie jest godny czci”[tamże: 52]. To, że racjonalna krytyka islamu ma zapewnioną mniejszą ochronę, niż antychrześcijańskie wulgaryzmy na Litwie i w Rosji, wydaje się być szczególnie niesprawiedliwe. $\mathrm{Z}$ tego powodu wielu filozofów i prawników apelowało do Wielkiej Izby o ponowne rozpatrzenie wyroku w sprawie E.S. przeciwko Austrii, aby w ten sposób Trybunał wyjaśnił swoje orzecznictwo. Podczas seminarium zorganizowanego na wysokim szczeblu przez Europejskie Centrum Prawa i Sprawiedliwości (ECLJ) w Radzie Europy, poświęconemu wolności wypowiedzi w sprawach religijnych [ECLJ 2018], kilku mówców wskazało na brak spójności tego orzeczenia, sprawiające wrażenie "podwójnych standardów” w zależności od tego, czy obraza uczuć religijnych dotyczy chrześcijan czy muzułmanów. Na przykład prof. Karine Bechet-Golovko porównała sprawy E.S. przeciwko Austrii oraz Marija Alochina i innych przeciwko Rosji (Pussy Riots): „Można by (...) pomyśleć, że sa już jakieś kryteria: kontekst (miejsce czynności, jej powtarzalność, jej treść) i waga wyroku, że sa one ze soba powiazane. Znów jednak obiektywizm ma trudności $z$ dojściem do głosu. Przecież z jednej strony mamy jedynie pozbawiona wulgarności przemowę wygłoszona poza miejscem sakralnym [E.S.], podczas gdy z drugiej strony poziom wulgarności jest bezsporny, a wypowiedź ma miejsce w świątyni [Pussy Riots]" [tamż $\left.\mathrm{e}^{5}\right]$.

5 Interwencja Karine Bechet-Golovko : „Wolność wypowiedzi w dziedzinie religii”. 
Apel skierowany do Wielkiej Izby poparło 62.000 osób, które podpisały petycję o prawo do krytykowania islamu w Europie ${ }^{6}$. Z inicjatywy ECLJ dwadzieścia osób życia publicznego we Francji podpisało także felieton w obronie prawa wypowiedzi w sprawach religijnych, który ukazał się w ogólnokrajowej gazecie ${ }^{7}$. Znaleźli się wśród nich byli muzułmanie, katoliccy badacze i intelektualiści, feministki i autorzy niereligijni, m.in. Waleed Al-Husseini, Rémi Brague, Chantal Delsol, Zineb El-Rhazoui, Annie Laurent, Boualem Sansal, Pierre-André Taguieff, Michèle Tribalat oraz ja sam. Wszyscy, do pracy, badań i prywatnej refleksji, musimy skorzystać z dużej wolności wypowiedzi na temat religii, w szczególności islamu. Zgodnie z treścią petycji jej sygnatariusze są zdania, że wyrok Izby z dnia 25 października 2018 r. naruszył wolność wypowiedzi pani Sabaditsch-Wolff. Apel został zakończony następującym stwierdzeniem: „pragniemy wyrazić wobec Trybunału nasze przywiazanie do debaty opartej na racjonalnych przesłankach, czy to natury politycznej, czy naukowej, oraz do prawa do krytykowania religii. $\mathrm{Na}$ szali leży przyszłość naszej cywilizacji”.

W odpowiedzi na wniosek o ponowne rozpatrzenie Trybunał mógł skorygować swój poprzedni wyrok. Zadecydował jednak tego nie zrobić, a nawet przyznał sprawie status „kluczowej”, to jest mającej stanowić wskazówkę dla wszystkich jurysdykcji krajowych. Wyrok przeciwko Elisabeth Sabaditsch-Wolff nie był zatem przypadkowy, ale wskazuje na nową orientację Trybunału, która wiąże się z wyzwaniami cywilizacyjnymi.

\section{IV. „Pokój religijny” za cenę prawdy i sprawiedliwości}

Trybunał nie uzasadnił swojej odmowy przekazania sprawy do Wysokiej Izby, jesteśmy tu zatem zdani jedynie na domysły. Wyrok Trybunału można postrzegać jako przesunięcie w kierunku wielokulturowości i gotowość do poświęcenia wolności wypowiedzi na rzecz wymogów, jakie niesie ze sobą życie razem i wielokulturowość. Trybunał stwierdził przecież, że chroni „ducha tolerancji” i „pokój religijny" [ECHR 2018: no. 38450/12, 57].

Taki wyrok stanowi jednak wyrzeczenie się ideału sprawiedliwości opartej na prawdzie, opowiadając się zamiast niej za relatywistyczną wersją „tolerancji”. A zatem to sędzia decyduje o tym, co wolno mówić, opierając się na swojej własnej koncepcji wspólnego życia i swoich obawach o reakcje tych, którzy mogą się poczuć

${ }^{6}$ ECLJ, „Brońmy prawa do krytyki islamu”, petycja podpisana przez 61.615 osób.

7 „Pour la défense de la liberté d'expression en matière religieuse”, Valeurs actuelles, 15 marca $2019 \mathrm{r}$. 
urażeni danymi uwagami. Ideał „pokoju religijnego” promowany przez wyrok Trybunału jest atrakcyjny, ale jego ceną jest wolność mówienia prawdy. Implikuje on bowiem, że każde stwierdzenie, nawet prawdziwe, może zostać potępione jako przejaw nietolerancji i podżegania do przemocy, gdy tylko stanowiący zagrożenie ludzie oświadczą, że czują się urażeni w swoich uczuciach religijnych.

Oczywiście prawdą jest, że pokój jest największym dobrem społeczności, dlatego w celu jego zachowania władze czasem ograniczają wolność poszczególnych osób. Jednak jak zauważył prof. Marko Milanovic, „uwaga skarżącej nie zostaŁa wypowiedziana $w$ kontekście, $w$ którym mogła bezpośrednio i nieuchronnie sprowokować słuchaczy do przemocy - skarżąca nie udała się na przykład w piątek do meczetu, by głosić wobec tam zgromadzonych osób, jakim szaleństwem było małżństwo Mahometa z Aisza" [Milanovic 2018]. Co więcej, postępowanie zostało wszczęte z inicjatywy dziennikarza, a nie organizacji islamskiej. Dlatego ograniczając wolność słowa Trybunał nie przyczynił się w znaczący sposób do tolerancji religijnej.

Na poziomie jeszcze bardziej fundamentalnym, relatywiści ze wszystkich stron zapytają: „Jakie znaczenie ma prawda dla zachowania pokoju?”. Jeżeli prawda nie istnieje, to rzeczywiście wolność wypowiedzi nie ma wielkiego znaczenia, a obowiązkową „tolerancję” należałoby narzucić wszystkim. Prawdziwego pokoju nie można jednak sprowadzać do powierzchownej nieobecności konfliktu i przemocy, próżne też byłyby wysiłki budowania go na kłamstwach czy relatywizmie.

Tradycja europejska uczy, że nie da się zaprowadzić trwałego pokoju bez prawdy i sprawiedliwości. Ponieważ zaś Europa od czasów starożytnych jest dziedzicem cywilizacji, która utożsamia Boga z prawdą i miłością, a nie z arbitralnością i siłą, wartości te uznajemy za najwyższe i nie umiemy sobie wyobrazić, jak prawdomówność miałaby obrazić Boga czy społeczeństwo. Dążenie do prawdy i poznanie Boga są tym samym. Jest to z pewnością źródło naszego przywiązania do racjonalnych badań i krytyki. Chcemy społeczeństwa, w którym „łaskawość i wierność spotkają się z sobą, ucałują się sprawiedliwość i pokój” [Ps 85, 11]. Sprawiedliwość i pokój, które cechują ideał każdej społeczności, wymagają tak miłości, jak i prawdy.

Elisabeth Sabaditsch-Wolff powiedziała prawdę. Jest krytykowana przede wszystkim za to, że zrobiła to w sposób „złośliwy”, czyli pozbawiony miłości. Cóż jednak wiemy na ten temat? I czy rolą sędziego jest sądzić czyjeś intencje? Co więcej, 
podnosząc taki zarzut zapomina się, że potępienie zła po to, by chronić społeczeństwo, pomimo pozorów szorstkości jest tak naprawdę aktem miłości.

\section{Podsumowanie}

Decyzja Trybunału poważnie ogranicza wolność wypowiedzi w kwestiach religijnych, co umożliwia skazanie kogoś nie na podstawie treści jego wypowiedzi, ale ze względu na przypisywane mu intencje. Czy nie jest absurdem podporządkowywanie wolności wypowiedzi dobrej woli? W szczególności, gdy dobrą wolę utożsamia się z nieszkodliwością.

To naruszenie wolności wypowiedzi usprawiedliwia się nowym pozytywnym obowiązkiem nałożonym na Państwa przez Trybunał, a polegającym na „zapewnieniu pokojowej koegzystencji wszystkich religii i tych, którzy nie przynależą do żadnej grupy religijnej, poprzez zapewnienie wzajemnej tolerancji”. W ten sposób każda wypowiedź, nawet prawdziwa, może zostać uznana za naganną jako wyraz nietolerancji religijnej, jeżeli mogłaby prowadzić do napięć społecznych. Jest to abdykacja europejskiego zmysłu krytycznego, a jednocześnie wsparcie potencjalnego potępienia wszelkiego świeckiego czy chrześcijańskiego prozelityzmu przeciwko muzułmanom. A przecież taki prozelityzm jest dziś bardziej potrzebny, niż kiedykolwiek wcześniej!

Decyzja ta to także smutna wiadomość dla wszystkich tych, którzy będąc muzułmanami, mają nadzieję znaleźć w Europie ochronę, jaka pozwoliłaby im stawić czoła obowiązującemu w islamie zakazowi krytykowania islamu oraz reinterpretacji Koranu i hadisów.

W końcu, decyzja ta podyktowana była lękiem przed muzułmanami. Trybunał mówi o tym wprost: władze austriackie słusznie potępiły tę wypowiedź, aby w ten sposób zachować „pokój religijny” w austriackim społeczeństwie. A więc kryterium akceptowalności wypowiedzi nie jest już prawda, ale przemoc, jaką może wywołać. Granice wolności słowa wyznacza zatem nie tyle przemoc spornej wypowiedzi, ale potencjalna przemoc ze strony tych, którzy twierdzą, że czują się nią urażeni. W ten sposób wystarczy, że kilka wzburzonych osób ogłosi, że czują się urażone, a jeżeli tylko będą one stanowić zagrożenie, wystarczy to, by uzasadnić cenzurę wymierzoną $\mathrm{w}$ ich przeciwników.

Oczywiście nie ma powodu do wynoszenia bluźnierstwa i wulgarności do rangi praw człowieka. Nie istnieje coś takiego, jak „prawo do bluźnierstwa”, ale prawo 
do wolności wypowiedzi, z którym wiąże się odpowiedzialność i pewne granice. Należy ograniczyć jedynie rozpowszechnianie obraźliwych i obscenicznych treści oraz podżeganie do bezpośredniej przemocy. Trzeba cenzurować obsceniczność i podżeganie do przemocy, ale nie krytykę. W tym jednak przypadku Trybunał postąpił dokładnie na odwrót: zastosował cenzurę wobec krytyki islamu, a jednocześnie zapewnił ochronę dla obscenicznych treści wymierzonych w symbole chrześcijańskie, w sposób bezprecedensowy popierając stosowanie cenzury.

Czas pokaże, czy ETPC będzie dalej kroczyć tą „wolnościową” ścieżką.

\section{Bibliografia}

Ahmari S. (2018), The Day Free Speech Died in Europe, "Commentary".

Armstrong S. (2018), The Case of E.S. v. Austria: What it Means for the Rights of Europeans, "Liberalistia".

Barker M. (2018), Imran Khan criticised for defence of Pakistan blasphemy laws, "The Guardian".

Bougiakiotis E. (2018), E.S. v Austria: Blasphemy Laws and the Double Standards of the European Court of Human Rights,"UK Constitutional Law Association".

Bukhari S., volume 5, book 58 .

Cottee S. (2018), A Flawed European Ruling on Free Speech,"The Atlantic".

Council for Human Rights (2015), Report of the Special Rapporteur on freedom of religion or belief (about the relationship between the right to freedom of religion or belief and the right to freedom of opinion and expression), Document A/HRC/31/18.

ECHR (1976), Handyside v. the United Kingdom (Plenary), no. 5493/72.

ECHR (1994), Otto-Preminger-Institut v. Autstria, no. 13470/87.

ECHR (2018), E.S. v. Austria, no. 38450/12.

ECHR (2018), Mariya Alekhina and others v. Russia, no. 38004/12.

ECHR (2018), Sekmadienis Ltd. v. Lituania, no. 69317/14.

ECHR (2019), Judgments of 19 March 2019, "Registrar of the Court", Press release 098.

ECLJ (2008-2010), Rapport soumis en Juin 2008 et actualisé en juin 2010.

ECLJ (2018), New challenges to the Freedom of Religion in Europe in the Light of the Recent Judgments of the ECHR, seminar organized at the Council of Europe.

Francois-Cerrah M. (2012), The truth about Muhammad and Aisha, The Guardian.

Government of Pakistan, Ministry of Information, Broadcasting \& National Heritage, Press Information Department (2018), Prime Minister Underscores the Importance of Respecting Religious Sentiments of all, "Press release No. 70".

Government of Pakistan, Ministry of Information, Broadcasting \& National Heritage, Press Information Department, "Press release", No. 175, Islamabad. 
Milanovic M. (2018), Legitimizing Blasphemy Laws Through the Backdoor: The European Court's Judgment in E.S. v. Austria, "European Journal of International Law".

Parliamentary Assembly of the Council of Europe (PACE) (2007), Blasphemy, religious insults and hate speech against people on grounds of their religion, "Recommendation 1805”.

Puppinck G. (2019), Blasphème contre Mahomet: Al-Azhar et le Pakistan se félicitent de la décision de la Cour européenne des droits de l'homme, "Valeurs actuelles".

Puppinck G. (2018), Délit de blasphème: "La CEDH n’est pas Charlie! », "Figaro Vox".

Rasmussen S. (2017), Pakistan: man sentenced to death for blasphemy on Facebook, "The Guardian".

Scott M. (2018), The ECtHR has not created a European blasphemy law but it has produced a lamentable judgment, "BarristerBlogger.com"

Smet S. (2018), E.S. v. Austria: Freedom of Expression versus Religious Feelings, the Sequel, "Strasbourg Observers".

Wood G. (2018), In Europe, Speech Is an Alienable Right,"The Atlantic”. 